\title{
Our experience with emergency ophthalmic surgery at Hospital Kuala Lumpur during the COVID-19 pandemic
}

Shu Yee Seow, Sabrina Abu Hassan Asaari, Jamalia Rahmat

Department of Ophthalmology, Hospital Kuala Lumpur, Wilayah Persekutuan Kuala Lumpur, Malaysia

\section{Abstract}

As Malaysia called to arms its front liners for the COVID-19 pandemic, Hospital Kuala Lumpur was converted into a hybrid hospital to handle both COVID-19 and non-COVID-19 patients. There was a reprioritization of services affecting all hospital units, including ophthalmology. We illustrate the challenges faced with two ophthalmic emergency cases that presented during this trying period: a case of left eye posterior globe rupture sustained through a motor vehicle accident and another case of right eye bleb leakage 3 weeks post-trabeculectomy.

This report highlights the various perioperative challenges faced by the ophthalmology team in managing these cases. Amongst them were logistic and technical challenges, which included the wait for COVID-19 test results, ophthalmic services scattered between three buildings, and the initial lack of guidelines. Disruption to our emergency ophthalmic workflow required adaptation and improvisation.

As we transition to resume "normal" ophthalmic services, healthcare centres will undergo frequent remodelling in their usual work processes to ensure that high standards of care are upheld whilst protecting healthcare workers.

Keywords: COVID-19, emergency ophthalmic surgery, healthcare management, pandemic 


\section{Pengalaman pembedahan kecemasan oftalmik di Hospital Kuala Lumpur semasa pandemik COVID-19}

\section{Abstrak}

Ketika Malaysia mempersiapkan barisan hadapannya untuk menghadapi pandemik COVID-19, Hospital Kuala Lumpur berubah menjadi hospital hibrid bagi merawat pesakit COVID-19 dan bukan COVID-19. Penyusunan semula perkhidmatan yang melibatkan semua unit termasuk Oftalmologi dibuat untuk memenuhi keperluan kepentingan perkhidmatan yang mendesak. Di sini kami menggambarkan cabaran yang dihadapi semasa tempoh yang sukar ini dengan dua kes kecemasan oftalmik: kes kecederaan perforasi bola mata kiri berikutan kenderaan bermotor dan kes kebocoran bola mata kanan yang berlaku 3 minggu selepas pembedahan trabekulektomi.

Laporan ini menyoroti pelbagai cabaran perioperatif yang dihadapi oleh pasukan oftalmologi dalam meguruskan kes-kes ini. Antaranya ialah cabaran logistik dan teknikal, termasuk penantian keputusan ujian COVID-19, perkhidmatan oftalmik yang tersebar melibatkan tiga bangunan berasingan, serta kekurangan garis panduan pada peringkat awal. Perubahan aliran kerja disebabkan oleh cabarancabaran ini memerlukan adaptasi dan improvisasi.

Dalam peralihan untuk menyambung semula perkhidmatan oftalmik dengan norma baru, pusat dan institusi kesihatan perlu melakukan perubahan dalam proses carakerja untuk memastikan piawaian penjagaan yang tinggi dipatuhi, dan dalam masa yang sama melindungi kakitangan kesihatan.

Kata kunci: COVID-19, pandemik, pembedahan oftalmik kecemasan, pengurusan penjagaan kesihatan

\section{Introduction}

The coronavirus disease 2019 (COVID-19) pandemic emerged from a highly infectious, newly discovered strain of single-stranded RNA coronavirus. ${ }^{1}$ The outbreak was first documented in Wuhan, China in December 2019. ${ }^{1}$ Malaysia recorded its first case of COVID-19 on January 25, 2020. ${ }^{2}$

To flatten the COVID-19 curve, Malaysia enacted a Movement Control Order (MCO) beginning March 18, 2020. During phases 1 to 4 of MCO, elective ophthalmologic procedures were placed on hold. A series of recommendations regarding ophthalmic practice was released to guide ophthalmologists globally on the 
provision of ocular care during these unprecedented times. ${ }^{3,4}$

During the COVID-19 pandemic, Hospital Kuala Lumpur (HKL) became a hybrid hospital, handling both COVID-19 and non-COVID-19 patients. As HKL reorganized its resources to tackle the pandemic, ophthalmology services had to adapt to significant changes.

This report illustrates our experience caring for two patients requiring emergency ophthalmic surgery during the peak of COVID-19 in Malaysia.

\section{Case 1}

A 48-year-old man presented to HKL after his motorcycle skidded at $4 \mathrm{pm}$, April 24, 2020. After initial management at the emergency department, he was admitted at midnight with left eye posterior globe rupture and right shoulder soft tissue injuries.

COVID-19 risk stratification, which consisted of temperature measurement and exposure screening questionnaires, deemed the patient low-risk. The patient had to undergo mandatory throat and nasal swabs for 2019-nCoV PCR which was taken at $12.15 \mathrm{am}$. These measures determined the level of personal protective equipment (PPE) required. During the wait, the patient was placed in the multidisciplinary transition ward and wore a three-ply surgical mask. The on-call pathologist was contacted to expedite testing, shortening the turnover time of verbal reporting from 24 to 12 hours. The following day, his result was available at $12 \mathrm{pm}$ and the anaesthesiologist on-call was informed immediately.

Left eye globe rupture repair was subsequently performed under general anaesthesia at $3 \mathrm{pm}$. The surgery was done in the designated non-COVID-19 operating theatre at the Paediatrics Institute (Paediatric Operating Theatre, POT). Postoperatively, the patient was monitored in the non-COVID multidisciplinary ward at Hospital Tunku Azizah (HTA, previously known as Women and Child's Hospital) (Fig. 1).

Although the visual prognosis was extremely poor for this patient, we were able to attain primary closure of the globe rupture within 24 hours. The patient was subsequently discharged well on postoperative day 3.

\section{Case 2}

A 57-year-old man, 3 weeks postoperative for right eye augmented trabeculectomy, attended clinic review on April 29, 2020 and underwent removal of releasable suture. A few hours later, he experienced gushing of fluid from his right eye. He then presented to HKL Ophthalmology Casualty Clinic at 4 pm, April 30, 2020 and was diagnosed with right eye postoperative bleb leakage, requiring resuturing. 
Case 1

Case 2

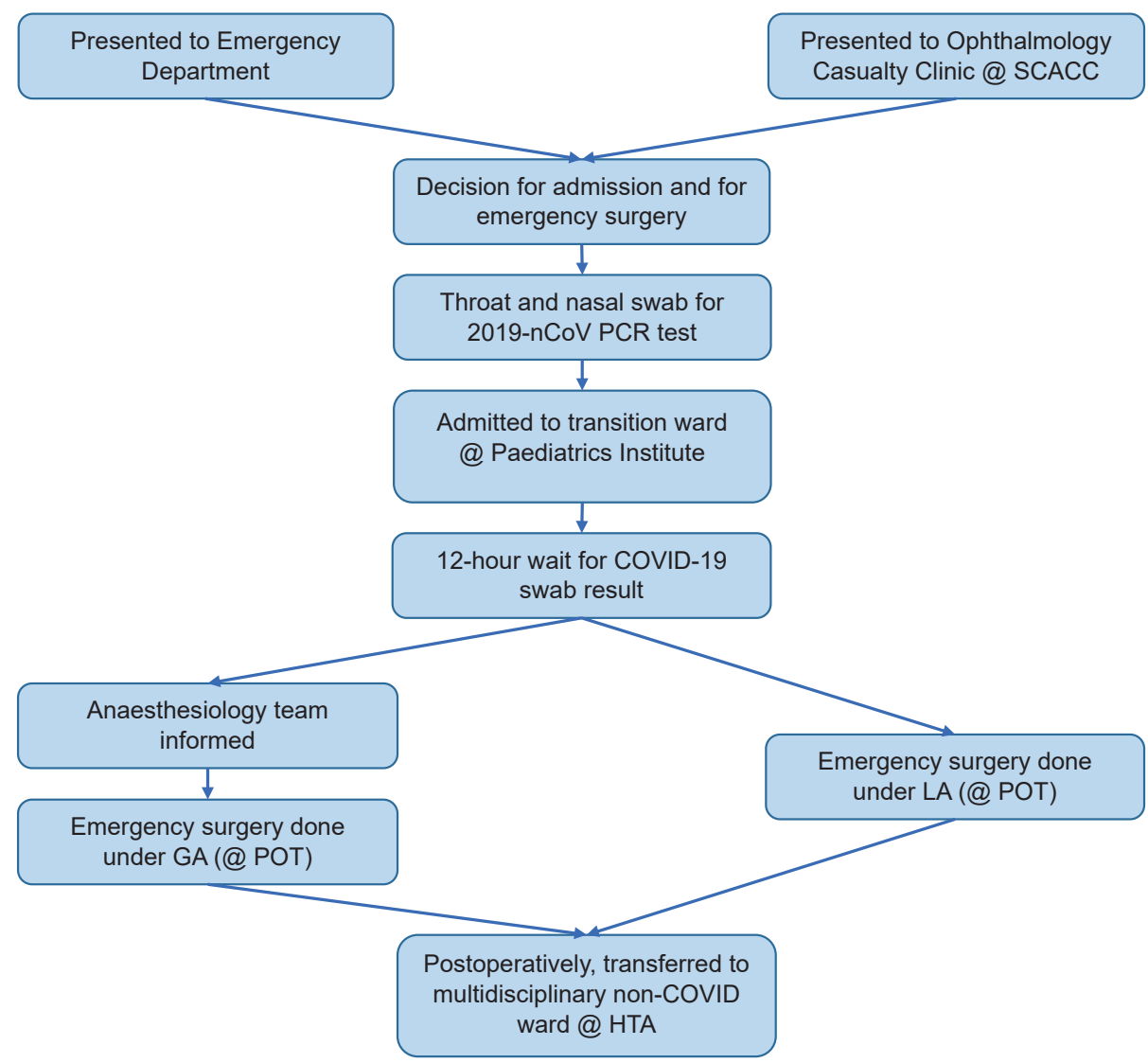

GA: general anaesthesia; HKL: Hospital Kuala Lumpur; HTA: Hospital Tunku Azizah; LA: local anaesthesia; POT: Paediatric Operating Theatre; SCACC: Specialist Complex and Ambulatory Care Centre

Fig 1. Summary of both patients' journey in HKL.

The anterior chamber appeared formed but shallow, the bleb was low-lying and diffuse, and the Seidel's test was positive over the limbal area.

The patient was evaluated similarly to case 1 . He was admitted and the throat and nasal swabs were performed at $6.30 \mathrm{pm}$. During the 12-hour wait in the transition ward, a bandage contact lens was placed and topical antibiotics intensified. Although the results were available the following morning at 6 am, the operating theatres were occupied. Resuturing of the right eye bleb leak was subsequent- 
ly performed under local anaesthesia at 11 am at POT. Postoperative care was provided at HTA's non-COVID multidisciplinary ward. The patient was discharged well on postoperative day 2 with a well-formed anterior chamber, diffuse bleb and Seidel's negative.

\section{Discussion}

HKL, located on 150 acres in the heart of Kuala Lumpur, is the largest public tertiary hospital in Malaysia with 53 departments and units, 83 wards and 2,300 beds. ${ }^{5}$

The Ophthalmology Department of HKL received 56,859 outpatient visits, admitted 6,559 patients, and performed 4,163 eye surgeries in 2019. The 36-bed ophthalmology ward is located in the main hospital block, one floor above the general operating theatre (GOT). The clinic is located in the Specialist Complex and Ambulatory Care Centre (SCACC), approximately 350 metres away (Fig. 2).

To cope with the increasing COVID-19 patient load, HKL repurposed wards and operating theatres to avail 700 inpatient beds. Health services and personnel were redistributed and surgical wards, including ophthalmology, were among those affected. HKL's main block was designated for the care of COVID-19 and severe

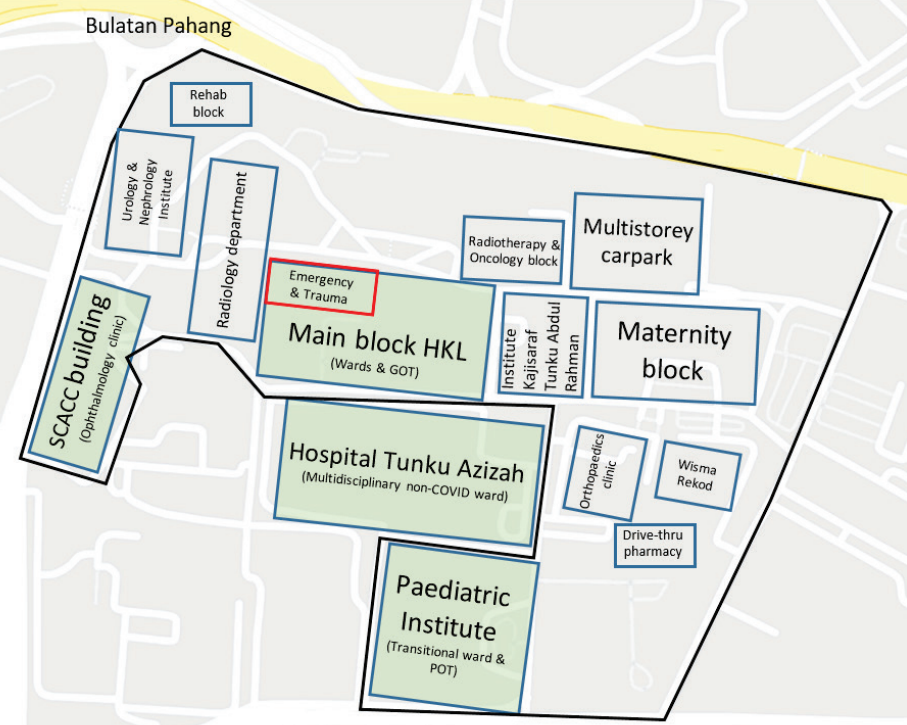

Fig. 2. Illustrated map of HKL. 
acute respiratory illness (SARI) patients. The GOT served as an additional intensive care unit, utilizing its ventilators.

The vacant Maternity Block and Paediatrics Institute, whose services were recently transferred to HTA, were reopened to serve as non-COVID and transition wards, respectively. The Ophthalmology Department was allocated a limited number of beds in the multidisciplinary ward at the newly opened HTA.

During the initial phases of COVID-19, generalized recommendations and cautions regarding ophthalmic cases and procedures were released, but standard operating procedures (SOPs) remained lacking. Contributing to the concern was the death of Chinese ophthalmologist Li Wenliang, which revealed possible transmission via conjunctival mucosa. ${ }^{1}$ Case reports describing conjunctivitis as a presenting feature of COVID-19 and the need for proximity between ophthalmologists and their patients further amplified the anxiety. ${ }^{1}$ A swift remodelling of outpatient and inpatient services was needed to continue delivering high standards of care without jeopardizing healthcare personnel safety.

Globally, emergency services battled with an overwhelming number of COVID-19 patients. Conversely, throughout MCO, the incidence of trauma requiring ophthalmic emergency surgeries drastically reduced at HKL. At the time of writing, there were only 10 ophthalmic emergency admissions during the MCO period, 4 of which were trauma-related, compared to 48 in the corresponding period of 2019.

The two cases illustrated occurred during the height of COVID-19, prior to the availability of SOPs for approaching emergency ophthalmic surgeries. HKL's "ophthalmology service under one roof" was scattered and logistics became an obstacle. Preoperatively, ophthalmology equipment, including the mobile microscope, were transported to POT. All admissions were swabbed for COVID-19 and placed temporarily in the Paediatrics Institute transition wards while awaiting results.

Intraoperatively, experienced surgeons aimed for swiftness and efficiency to minimize exposure time and risk. However, the unfamiliar POT setting posed challenges. When additional equipment was needed, the circulating nurse had to obtain them from a different location, causing delay. There were also conflicts and trade-offs over PPE such as the need for face shields or eye goggles intraoperatively, which may compromise the surgeon's visibility.

Postoperatively, patients received care in the non-COVID multidisciplinary ward at HTA. Fortunately, it was located opposite the Paediatric Ophthalmology ward of HTA. This allowed us access to specialized ophthalmology equipment such as slit lamps and B-scan needed for examinations. 


\section{Reflection}

Ophthalmology is a field highly dependent on specialized equipment. Location and equipment mobilization have a huge influence on our workflow. With the HKL emergency ophthalmology service stretched across three separate buildings, there was delay associated with equipment availability. We learned to better anticipate and over-prepare for emergency surgeries to reduce delays associated with lacking instruments and supplies.

The delay in surgical intervention resulting from the turnover time of the swab results may negatively impact patient outcomes. As the decision-maker, the attending ophthalmologist must always remain vigilant, balancing urgency and safety. This was demonstrated in the above two cases, in which the risk of complications associated with a delay in surgical intervention was minimized whilst also ensuring the wellbeing of healthcare staff.

In the absence of physical gatherings, virtual platforms are playing an increasingly crucial role in updating ophthalmologists with the latest information. Such channels of communication ensure that our guidelines and SOPs are in sync with the latest knowledge. At the time of writing, the Malaysian guidelines for ophthalmologists were recently released in May 2020 to advise us in these uncertain times. ${ }^{6}$

\section{Conclusion}

Our distinct experience in handling emergency ophthalmic surgery was influenced by HKL's layout and its status as a hybrid hospital during the pandemic. COVID-19 posed a multitude of challenges and difficulties to ophthalmologists in delivering care. Our team had to adapt to the restructuring of HKL, optimize the delivery of emergency ophthalmic care across three buildings, as well as overcome the unfamiliar surroundings of the operating theatre and the multidisciplinary ward.

Despite this, excellent teamwork and communication enabled us to make the best out of the situation. We must learn from our COVID-19 experience and be proactive in designing an agile ophthalmology service. As the situation evolves, SOPs and workflows will continue to evolve to accommodate both COVID-19 and non-COVID-19 patients safely. Ophthalmologists should not take for granted the transition to "normal" service. Planning and designing operational flow in wards, clinics, and operating theatres must reflect our acquired knowledge and that of the rest of the world. 


\section{Acknowledgments}

We would like to thank the Director General of Health Malaysia for his permission to publish this article. We would also like to thank Dr. Navin Naidu for editorial assistance.

\section{References}

1. Sadhu S, Agrawal R, Pyare R, et al. COVID-19: Limiting the Risks for Eye Care Professionals [published online ahead of print, 2020 Apr 20]. Ocul Immunol Inflamm. 2020;1-7. doi:10.108009273948.2020 .1755442 .

2. Sipalan J, Holmes S. Malaysia confirms first cases of coronavirus infection. Reuters. Available from: https://www.reuters.com/article/china-health-malaysia/malaysia-confirms-first-cases-of-coronavirus-infection-idUSL4N29U03A (Accessed 17 May 2020).

3. CDC, WHO. Important coronavirus updates for ophthalmologists. https://www.aao.org/headline/ alert-important-coronavirus-context (Accessed 17 May 2020).

4. Royal College of Ophthalmologists. RCOphth COVID-19 Clinical guidance and national information. available from: https://www.rcophth.ac.uk/about/rcophth-covid-19-response/ (Accessed 17 May 2020).

5. Hospital Kuala Lumpur, Ministry of Health Malaysia. Introduction. Available from: http://www.hkl. gov.my/index.php/about-us/introduction (Accessed 24 May 2020).

6. Guidelines for ophthalmologists during COVID-19 pandemic in Malaysia (May 2020). 